\title{
Universiteit
}

Leiden

The Netherlands

\section{The Lorax Complex: Deep ecology, Ecocentrism and Exclusion} Kopnina, H.N.

\section{Citation}

Kopnina, H. N. (2012). The Lorax Complex: Deep ecology, Ecocentrism and Exclusion. Journal Of Integrative Environmental Sciences, 9(4), 235-254. doi:10.1080/1943815X.2012.742914

Version: $\quad$ Not Applicable (or Unknown)

License: $\quad$ Leiden University Non-exclusive license

Downloaded from: $\quad$ https://hdl.handle.net/1887/43838

Note: To cite this publication please use the final published version (if applicable). 
This article was downloaded by: [Dr Helen Kopnina]

On: 12 December 2012, At: 12:07

Publisher: Taylor \& Francis

Informa Ltd Registered in England and Wales Registered Number: 1072954 Registered

office: Mortimer House, 37-41 Mortimer Street, London W1T 3J H, UK

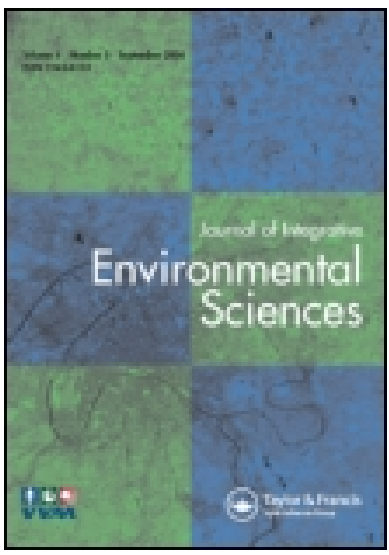

\title{
J ournal of Integrative Environmental Sciences
}

Publication details, including instructions for authors and subscription information:

http:// www.tandfonline.com/loi/ nens20

\section{The Lorax complex: deep ecology, ecocentrism and exclusion}

\author{
Helen Kopnina ${ }^{a}$ \\ a The Hague University of Applied Science, International Business \\ Management Studies, University of Applied Science, The Hague, \\ The Netherlands \\ Version of record first published: 12 Dec 2012.
}

To cite this article: Helen Kopnina (2012): The Lorax complex: deep ecology, ecocentrism and exclusion, J ournal of Integrative Environmental Sciences, 9:4, 235-254

To link to this article: http:// dx.doi.org/ 10.1080/ 1943815X. 2012.742914

\section{PLEASE SCROLL DOWN FOR ARTICLE}

Full terms and conditions of use: http://www.tandfonline.com/page/terms-andconditions

This article may be used for research, teaching, and private study purposes. Any substantial or systematic reproduction, redistribution, reselling, loan, sub-licensing, systematic supply, or distribution in any form to anyone is expressly forbidden.

The publisher does not give any warranty express or implied or make any representation that the contents will be complete or accurate or up to date. The accuracy of any instructions, formulae, and drug doses should be independently verified with primary sources. The publisher shall not be liable for any loss, actions, claims, proceedings, demand, or costs or damages whatsoever or howsoever caused arising directly or indirectly in connection with or arising out of the use of this material. 


\title{
The Lorax complex: deep ecology, ecocentrism and exclusion
}

\author{
Helen Kopnina* \\ The Hague University of Applied Science, International Business Management Studies, \\ University of Applied Science, The Hague, The Netherlands
}

(Received 7 June 2012; final version received 18 October 2012)

\begin{abstract}
Biodiversity preservation is often viewed in utilitarian terms that render nonhuman species as ecosystem services or natural resources. The economic capture approach may be inadequate in addressing biodiversity loss because extinction of some species could conceivably come to pass without jeopardizing the survival of the humans. People might be materially sustained by a technological biora made to yield services and products required for human life. The failure to address biodiversity loss calls for an exploration of alternative paradigms. It is proposed that the failure to address biodiversity loss stems from the fact that ecocentric value holders are politically marginalized and underrepresented in the most powerful strata of society. While anthropocentric concerns with environment and private expressions of biophilia are acceptable in the wider society, the more pronounced publicly expressed deep ecology position is discouraged. "Radical environmentalists" are among the least understood of all contemporary opposition movements, not only in tactical terms, but also ethically. The article argues in favor of the inclusion of deep ecology perspective as an alternative to the current anthropocentric paradigm.
\end{abstract}

Keywords: anthropocentrism; biodiversity; deep green ecology; ecocentrism; environmental ethics; environmental values; radical environmentalism; representation

\begin{abstract}
For most people, the idea of harming humans to liberate animals or prevent timber sales is unconscionable and misanthropic. The average person wonders how activists can justify threatening children in order to save guinea pigs. Aren't the medical and health needs of humans, for example, more important than the suffering of a rodent? Animal liberationists respond that most people are hopelessly blinded by speciesism and that animal suffering to benefit humans is morally wrong. Environmental "monkeywrenchers" adopt an equally radical stance; after all, what good are natural resource extraction, private property, and profit making if the Earth itself is destroyed by mankind?
\end{abstract}

Eco-Terrorism: Radical Environmental and Animal Liberation Movements (Liddick 2006:82).

\section{Introduction}

Based on a large number of international opinion polls, it appears that concern for the environment is on the rise and may be universal (Dunlap and York 2008).

\footnotetext{
*Email: h.kopnina@hhs.nl 
Exactly 40 years ago, the Club of Rome predicted in a study titled The Limits to Growth that population growth, industrialization and resource depletion would ultimately inhibit the global economy's ability to expand and in rapid loss of biodiversity (Meadows et al. 1972).

Despite the announcement by the United Nations Decade on Biodiversity 20112020, the current loss of species is estimated by experts to be between 1000 and 10,000 times higher than the natural extinction rate (WWF 2012).

The failure of the current framework to explicitly address the needs (and the very survival of) non-human species calls for an exploration of alternative paradigms (Kopnina 2012b). This article aims to examine what alternative approach to representation of biodiversity is possible and what type of advocacy may be needed in order to adequately address the loss of biodiversity. Who are the human advocates, "who speak for nature?" (O'Neill 2006). Those committed to the struggle of "radical environmentalism" or animal liberation are among the least understood of all contemporary opposition movements, not only in tactical terms, but also ethically and philosophically (Best and Nocella 2004; Churchill 2004). This article will therefore reflect upon the question of what are the present-day causes for this lack of understanding (in science and society) as well as on possibility to reduce this lack of understanding.

\section{Representations of biodiversity}

In the current paradigm, two approaches can be distinguished in regard to biodiversity and representation. One is an "economic capture" approach, which advocates the extension of the existing economic methods to include ethical concerns (Spash 2009). The other one is a "moral expert" approach which confines economic methods to the analysis of welfare gains, and assumes committees of ethical experts will complement economic expertise (O’Neil and Spash 2000). We shall examine each of these approaches in turn. We shall discuss environmental ethics and environmental psychology in order to address alternative approaches in regard to biodiversity.

\subsection{Economic value of biodiversity}

Rather than addressing the limits to growth, the new rhetoric of sustainable development (Brundland Report 1987) recast limits to growth debate as an opportunity to balance social, economic, and environmental needs. The secretary general of the United Nations (UN), Ban Ki-moon, said, "We need to chart a new, more sustainable course for the future, one that strengthens equality and economic growth while protecting our planet" (UN News Center 2012). Rio + 20 UN Conference on Sustainable Development held in June 2012, promotes

(1) Human sustainability: maintaining human capital such as health.

(2) Social sustainability (organizations and networks) and maintaining social capital: cultural, language, shared rules, laws, etc.

(3) Economic (financial) sustainability: keeping capital intact

(4) Natural (environmental) sustainability: Protecting natural capitals (e.g. water, land, air, minerals, etc.) 
This framing of "environment", "nature", "wilderness", or "biodiversity" as a common good puts a price on "ecosystem services" or "natural capital" eighties (e.g. De Groot 2002). The World Bank's mission statement on sustainable development frames biodiversity as an economic asset:

The World Bank's mission is to alleviate poverty and support sustainable development. Biological resources provide the raw materials for livelihoods, sustenance, medicines, trade, tourism, and industry. Genetic diversity provides the basis for new breeding programs, improved crops, enhanced agricultural production, and food security. Forests, grasslands, freshwater, and marine and other natural ecosystems provide a range of services, often not recognized in national economic accounts but vital to human welfare (The World Bank 2012)

The Economics of Ecosystems and Biodiversity (TEEB), a major international initiative hosted by the United Nations Environmental Program (UNEP) with financial support from the European Commission draws attention to the global economic benefits of biodiversity, warns that our neglect of the natural services provided by biodiversity is an economic catastrophe of an order of magnitude greater than the global economic crisis:

The irreversible loss of natural diverse genetic resources impoverishes the world and undermines our ability to develop new crops and medicines, resist pests and diseases, and maintain the host of natural products on which humans rely (http://www.teebweb.net/).

\subsection{Limits of economic capture approach}

However, there is a debate about exactly how much biodiversity needs to be preserved. Is a human-centered utilitarian perspective sufficient to protect all biodiversity? While Isbell et al. (2011) argue that plant biodiversity needs to be preserved in order to benefit complex human systems, others argue that preservation of "some" biodiversity would be sufficient to satisfy human needs. In provocative publication Plastic Panda, Haring (2011) argues that only some select species are needed for human survival and welfare, and that most of these species are domesticated and "adopted" for human needs rather than "wild". In fact, monocultures such as genetically manipulated crops or cattle will satisfy most of human needs (Haring 2011). Biodiversity protection is not necessarily contingent with social and economic interests, such as deriving medicines from wild plants (Crist 2003). The limits-to-growth or sustainable development framework may be inadequate in addressing biodiversity loss because

Mass extinction could conceivably come to pass without jeopardizing the survival of the human species; and because people might be materially sustained by a technologically biora made to yield services and products required for human life (Crist 2003:65).

Recently, some authors have argued that market-based valuation techniques are inadequate as they do not seem to capture the expanse, nuances, and intricacies of many of the ecosystem services as well as ecological identity and emotional attachments to nature the value of which is not readily understood by the economists (Kumar and Kumar 2008). Critics have noted that green GDP requires measurement 
of the benefits arising from public goods provided by nature for which there are no market indicators of value (Boyd 2007).

In the words of David Quammen (1998):

If the world's air is clean for humans to breathe but supports no birds or butterflies, if the world's waters are pure for humans to drink but contain no fish or crustaceans or diatoms, have we solved our environmental problems? Well, I suppose so, at least as environmentalism is commonly construed. That clumsy, confused, and presumptuous formulation "the environment" implies viewing air, water, soil, forests, rivers, swamps, deserts, and oceans as merely a milieu within which something important is set: human life, human history. But what's at issue in fact is not an environment; it's a living world ...

It is thus questionable whether purely economic approach to biodiversity conservation is adequate to address the loss of all species. Similar point can be made about different types of animals - those kept for consumption (farm animals), medical experimentation and companionship (pets) or entertainment (zoos, circuses) and those "left over". To take a historical perspective on human-animal relationships, Shepard (1993) made a clear distinction between wild animals and those that we use as companions or as food:

From this metonymic stew of animal as friend and object emerges the paradox that primal peoples kept their distance from animals - except from their in-taking as food or prototypes - and could therefore love them as sacred beings and respect them as other "peoples" while we, with the animals in our laps and our mechanized slaughterhouses, are less sure of who they are and therefore who we are (Shepard 1993:289).

An alternative approach might thus be needed.

\section{Environmental ethics: Anthropocentria/ecocentric continuum}

Environmental problems are associated with ethics through a number of issues, such as justice in the distribution of natural resources (such as timber) and burdens (such as pollution), fairness in the processes of environmental decision-making, and the moral claims of future generations of humans (O'Neill and Spash 2000). The sustainable development discourse is permeated by the "global ethic" of caring for the poor and reducing inequality (United Nations 2012; World Bank 2012). However, this global rhetoric rarely includes environmental ethics.

Early inspirations for environmental ethics writers were English poet William Wordsworth, and American transcendentalist writers, Henry David Thoreau and Ralph F. Waldo Emerson, and later an American ecologist and environmentalist Aldo Leopold. Environmental ethics posed a challenge to traditional anthropocentrism by questioning the assumed superiority of human beings to members of other species and by investigating the possibility of rational arguments for assigning intrinsic value to the natural environment and its non-human contents (Brennan and Lo 2002). Anthropocentric and ecocentric values can be placed on a continuum varying from weak to strong anthropocentrism, as "deep" or "shallow" ecology (Naess 2001).

Anthropocentric thinkers treat modern societies as "exempt" from ecological constraints and to share belief in human (technical) ingenuity and ability to solve environmental or social problems (Catton and Dunlap 1978; Dunlap and Catton 
1979, 1983; Kopnina, 2012a, 2012b, 2012c). In anthropocentric thought, humans are largely in control of the surrounding world and that problems arising from modern living can be taken care of through technological development (Lundmarck 2007). Ecocentric theorists postulate that the current ecological crisis stems from the "arrogance of humanism" (Ehrenfeld 1978).

Sustainable development advocates often subscribe to "shallow ecology" which encompasses concerns that connect human health, wealth and environment, the central objective of which is welfare of people in the developed countries (Kopnina 2012a,b). In anthropocentric view, animal rights are subservient to human rights and can be thought about at best when human rights are fully addressed, or at worst a non-issue (Finsen and Finsen 1994; Desmond 2013). Our acts toward animals are judged on the basis of how they affect human beings only and not on how they affect other species (Guither 1998; Nibert 2002). While sexism and racism are easily acknowledged in the contemporary Western liberal society, specieism is treated as a non-issue (Watson 1993; Best and Nocella 2011).

By contrast, deep green ecology is concerned about the intrinsic value of "nature" or "environment" with or without humans and rights that are associated with this value (Devall and Sessions 1985; Regan 2001). While in anthropocentric thought, concerns center around individuals or groups within one species (men and women, different ethnic groups, individuals with sexual orientations) and rights can be attributed on the basis of group characteristics or possessions (the rich and the poor). Discriminating human minorities or creating wealth inequality is seen as morally "bad" by current Western neo-liberal intellectuals, such the author's academic colleagues.

Within deep ecology, there is an ethical debate as to what degree intrinsic value should be attributed to individuals within the species (Regan 1984), entire species (Taylor 1991; Ferry 1995) or even entire ecosystems (Singer 1975; Regan 2003; DesJardins 2005). Ecocentric thinkers argue that if moral considerations underlying present-day social issues such as racism, sexism, and wealth inequality are to be extended to other species, the contrast in ethical values and anthropocentric bias is quite striking.

While the utilitarian attitude to nature seems almost common-sense, as human survival and economic growth are dependent on energy and material resources that are extracted from natural ecosystems (Rees 1992), the non-anthropocentric perspective is more difficult to explain. Many scholars of environmental ethics have agreed that an environmental ethic should explicitly consider the consistency of our environmental actions with our values (Seligman 1989).

\section{Environmental psychology}

Environmental psychology provides a number of theories explaining individual predisposition to environmental behavior. Hungerford and Volk (1990) distinguish between "entry-level variables" predisposing people to take an interest in the environment; "ownership variables" such as a personal investment in certain environmental issues, and "empowerment variables" including skill in using environmental action strategies and the belief that one can be successful. Environmental psychology and sociology studies are anchored in research on values, beliefs, and attitudes as well as studies addressing actual observed and self-reported behavior (Weigel and Weigel 1978). However, while most people in modern industrial societies agree there is a moral need to conserve nature and yet "burgeoning lists of threatened 
species and ongoing habitat destruction show that these so-called values are failing to motivate sufficient political and social pressure for conservation reform" (Booth 2009:54).

Many theories try to explain the widespread rhetoric-behaviors gap, ranging from insufficient individual motivation for environmental protection (e.g. Hartig et al. 2007) and political constraints such as the influence on government decision-making of corporate and industrial lobbies (e.g. Crossley and Watson 2003).

There are many studies and measurements translating of beliefs, values and attitudes into environmentally significant behavior published in the journals of Environment and Behavior, Journal of Environmental Psychology, Journal of Environmental Ethics, Environmental Education Research, etc. over the past decades. However, these publications only partially explain why certain individuals, who, for example, grew up in the same village next to the forest and witnessed its destruction, will agree to work for the logging company, while others growing up in the same village will defend the trees from being felled (Fisher 2002). Similarly, why would some individuals express concern about the loss of biodiversity while others from the same socio-economic class would view the loss of non-human life as a non-issue?

At least three value bases for environmental concern can be distinguished: selfinterest, humanistic altruism, and biospheric altruism (Dietz et al. 2005). The first two value objects can be described as anthropocentric, the last one is ecocentric (Schultz 2001). For both self-interest or altruistic humanists, human beings are seen as generally more worthy than members of other species (Devall and Sessions 1985; Drengson and Inoue 1995). While anthropocentric perspective assigns only instrumental values to other species, biospheric altruism is an extension of concern beyond the human boundary (Amérigo et al. 2007) and acknowledges intrinsic value of non-human species (Dietz et al. 2005:344).

Developmental studies of people's environmental behaviors and attitudes shed some light upon this altruistic predisposition to nature. The value-belief-norm theory indicates that people assigning intrinsic value to environment outside humans or perceiving environmental value in utilitarian terms serve as entry-level variables (Schwartz 1977; Stern et al. 1993, 1998, 1999). The retrospective research on the "significant life experiences" explain differences in environmental attitudes by distinct experiences of the natural world acquired in early childhood (for example, see Korhonen and Lappalainen 2004; Louv 2005). The hypothesis that the early childhood encounters with nature are crucial for development of positive environmental values is supported by retrospective reports of environmentalists, which are replete with stories of early and memorable encounters with pristine nature, such as free play, hiking, camping, fishing and berry picking (Kahn and Kellert 2002). Other formative experiences constitute experiences in organizations like the scouts or student environmental groups (Dawson 2007), witnessing the destruction or pollution of a valued place, and reading books about nature and the environment (Chawla and Cushing 2007:440).

\section{Biophilia hypothesis}

Edward O. Wilson proposed the idea that natural selection has resulted in an adaptive love of life-forms and life-like processes in humans. The term "biophilia", meaning "love for life" (Wilson 1984) refers to the existence of a fundamental, 
genetically-based human need and propensity to affiliate with other living organisms. According to this hypothesis, humans have an innate connection to the natural world, and our continued divorce from it has led to the loss of not only "a vast intellectual legacy born of intimacy" with nature but also our very sanity (Kellert and Wilson 1995). The term is used by many social and natural scientists within an interdisciplinary framework for investigating the human affiliation with nature. A review of the biophilia literature (e. g. Kahn 1997) sets into motion three overarching concerns. One concern focuses on the genetic basis of biophilia (e.g. Levy 2003). A second concern focuses on how to understand seemingly negative affiliations with nature within the biophilic framework. A third focuses on the quality of supporting evidence and whether the biophilia hypothesis can be disconfirmed (e.g. Joye and van den Berg 2011). The critics question the faith shown in the evolutionary explanation for human relationships to other species and the assumptions surrounding biophilia. Empirical cases testifying to the short-termism, anthropocentrism, systems control and narrow species preferences present in public and political arenas (e.g. Ojala and Lidskog 2011) suggest that biophilia might not be that strongly wired into human psyche.

\subsection{The Lorax complex}

It is these three interdependent dimensions - one emotional (the feeling of sadness when something valued gets destroyed); another one cognitive (the judgment that it is wrong to destroy this valued object); and the third one philosophical (intrinsic value of nature) that provide the basis of biocentric or ecocentric deep green ecology perspective we shall hereby refer to as "The Lorax complex". Some researchers of environmental movement also refer to religious (Taylor 2010) positions that encompass emotion and compassion expressed toward other species (Munro 2001).

\section{The radicalization of environmental movement}

Radical environmentalism and animal rights extremism might have emerged from societal and political rejection (Merchant 1992; Masters 2004; Zimmerman 1994; Liddick et al. 2010). Disaffected environmentalists and animal rights advocates often drawn from the same pool of concerned individuals that comprises the memberships of groups such as Greenpeace, the Wilderness Society, and People for the Ethical Treatment of Animals (PETA) who have turned from political lobbying and lawful protest to direct action (Zimmerman et al. 2001; Wolfe 2003; Sunstein and Nassbaum 2004). As traditional methods for bringing about change fail, or do not bring change quickly enough, disaffected activists break off and form a new group or movement that advocates more extreme methods (Liddick 2006:1).

Eco-terrorism is defined by the FBI's Domestic Terrorism Section as "the use or threatened use of violence of a criminal nature against innocent victims or property by an environmentally-oriented, subnational group for environmental-political reasons, or aimed at an audience beyond the target, often of a symbolic nature" (US Department of Justice 1993). Radical environmental groups engaged in ecotage - or economic sabotage of inanimate objects thought to be complicit in environmental destruction - have been identified as the leading domestic terrorist threat in the post9/11 "war on terror" (Vanderheiden 2004). 
Liddick traces progressive radicalization of organizations within the environmental rights movement: The Wilderness Society - Greenpeace - Sea Shepherd Conservation Society - Earth First! - Earth Liberation Front (ELF). Since radical biocentrists blame industrialization for destroying their most valued substance, the earth, many do not hesitate to "alleviate" this problem through destructive actions against perpetuators and their property (Arnold 1997). The progressively immoderate methodology adopted by animal rights and environmental activists, beginning with legal protest and lobbying, advances to civil disobedience, and graduating to major acts of property destruction (Liddick 2006:78-79). The act of destruction is seen as morally justified as "When we destroy something created by Humans we call it vandalism, but when we destroy something created by Nature, we call it progress" (Begley 2009:1).

For ecocentric activists, the rights of non-human species has the same moral imperative as the earlier social movements to liberate slaves, women, homosexuals and other "minorities" from dominant hegemonies.

Members of the animal liberation and radical environmental movements are motivated by a belief that what they do is absolutely necessary and just. The exploitation of animals is no different from the abuse and extermination of Jews during the Holocaust, and crimes committed to end the abuse and to free animal "slaves" are every bit as noble as the actions taken by those abolitionists who ran the Underground Railroad in the American South. Activists see attacks on governments and corporations that defile nature as just actions in defense of the Earth itself; indeed, without radical actions, including crimes, they are convinced that much of life on the planet will cease to exist. The sincerity and depth of feeling among animal rights and environmental extremists should not be doubted, and it is exemplified by ALF [Animal Liberation Front] activists who risk legal penalties and see value in freeing the smallest animal, be it a guinea pig, mouse, or snail (Liddick 2006:82).

According to Taylor (2008), radical environmentalists are characterized by their diagnoses and prescriptions regarding the environmental crisis.

Their diagnoses generally involve a critique of the dominant streams of occidental religion and philosophy, which, radical environmentalist argue, desacralize nature and thereby promote its destruction. In addition to aggressive and passionate resistance to such destruction, prescriptions generally include "reconnecting" with and "resacralizing" nature, as well as overturning the anthropocentric and dualistic beliefs they believe alienate people from nature and produce an ideology of human superiority that precludes feelings of kinship with other life forms. The most decisive perception animating radical environmentalism, however, is that the earth and all life is sacred and worthy of passionate defense (Taylor 2008:28).

At the emotional level, the outrage felt by deep ecology supporters is well-expressed by Dave Foreman, a cofounder of the radical environmental movement Earth First!, who uses the following metaphor to justify criminal actions in defense of the environment:

If you come home and find a bunch of Hell's Angels raping your wife, your old mother, and eleven-year-old daughter, you don't sit down and talk balance with them or suggest compromise. You get your twelve gauge shotgun and blow them to hell... There are people out there trying to save their mother [Mother Earth] from rape (Foreman 1982:4)." 
While some radical environmentalists may perceive humans as a threat to the planet ("Screaming Wolf" 1991), others integrate them as part of the planet as ecocentrism actually very much views humans as part of the ecosphere (Rosebaugh 2004). For example, Paul Watson the founder of Sea Shepherd Conservation Society strongly prohibits harming any living thing. In his statement on Ecocentrism homepage, Watson states:

I am pro-life: Meaning that I am anti-war and I respect the need for every child, cub, pup, kitten, hatchling and lamb to have the right to be brought into a world that is clean where they can be raised with love, nurturing, nourishment, and education (http:// www.ecospherics.net/pages/wonw.htm).

While there may be no official leaders in environmental movements, in the realm of animal rights and environmental radicalism there are nevertheless authors, public figures, and press officers who provide inspiration and ideological support (Liddick 2006:70). Ingrid Newkirk, Peter Singer, Steven Best, Edward Abbey, Paul Watson, Craig Rosebraugh, Leslie James Pickering, and Dave Foreman provided inspiration for the environmental movement. Some environmentalists represented "martyrs" of the movement, such as Barry Horne and William C. Rodgers, both of whom died while incarcerated for animal liberation crimes. Rodgers, an American environmental activist, left a suicide note in his prison cell on 21 December 2005:

To my friends and supporters to help them make sense of all these events that have happened so quickly: Certain human cultures have been waging war against the Earth for millennia. I chose to fight on the side of bears, mountain lions, skunks, bats, saguaros, cliff rose and all things wild. I am just the most recent casualty in that war. But tonight I have made a jail break - I am returning home, to the Earth, to the place of my origins (Quoted in Wikipedia, Radical environmentalists).

Active environmentalism espousing deep green values seems unacceptable to the mainstream society influenced by (and some would argue influencing) industrial neo-liberal politicians and corporate lobbies (Switzer 2003; Scarce 2004, 2005; Scruton 2012). As Rik Scarce (2011a) reflected in his commentary on the documentary If A Tree Falls: A Story of The Earth Liberation Front (http:// www.imdb.com/title/tt1787725/):

When I describe my research on radical environmentalists to new acquaintances, inevitably they say, "Oh, you mean you write about the eco-terrorists." There is no greater stigma in our society than that of "terrorist." No one listens to terrorists. Their arguments fall on deaf ears. They are imprisoned, and Daniel McGowan is, under extreme conditions reminiscent of the terrorism suspects at Guantanamo. So the ELF's penchant for destruction - never mind that no human life has ever been lost as a result of their actions - allows it to be painted as a terrorist group.

While studies of anthropocentric and ecocentric attitudes have indicated that people with ecocentric orientation are much more likely to actually act upon their values in order to protect the environment than those with anthropocentric orientations (Thompson and Barton 1994; Kortenkamp and Moore 2001). Studies indicate that only biospheric altruism-centered approach leads to sacrifice rather than quality-of-life solutions to environmental problems (Kaplan 2000). Yet, the means of this action need to be carefully weighed. 
Where there is enough commitment there is no stopping activists from pursuing their struggle. The flip side is that the oppression of dissent is in the interests of powerful corporations that depend on destroying the planet, and they are supported by law enforcement. And so a conflict is inevitable. Will the conflict result in illumination and broader social activism? Probably only if that conflict has profound moral overtones overtones that are lost once property destruction enters the picture (Scarce 2011b).

\subsection{The causes of marginalization of deep green perspective}

While the "radicals" might be extremely disappointed with the lack of support from the mainstream environmental organizations and anthropocentrically inclined individuals, the most strategic political choice may still be peaceful collective lobbying for the ecospheric interests. On the other hand, without general public's and governments support, and with continuing demonization of "eco-warriors" the ecospheric interests are not likely to be recognized. The solution, however naïve, thus may lie in integrating deep ecology ethic in the mainstream political apparatus to avoid both extremism and to achieve a true planetary sustainability. While the author realizes that such integration might not be realistic in the current sociopolitical climate, ignoring deep green perspective as "one of many" (at best) visions is not likely to result in resolution of severe environmental issues such as biodiversity loss.

Can anthropocentrism be said to be universal or culturally specific?

\section{Cross-cultural views: view from anthropology}

Anthropological literature indicates that this emotional attachment might be crosscultural and possibly universal (Milton 2002). There is evidence that environmental concern is not limited to affluent societies, as proponents of post-materialist values hypothesis (Inglehart 1977) state, but is a truly universal phenomenon (Taylor 1993). Intercultural studies indicate that despite differences in nationality and profession, people exhibit biospheric altruism coinciding with the childhood experiences that distinguish environmentally active respondents from those who show less commitment (Wells and Lekies 2006).

There has been a proliferation of grassroots environmental organizations in developing countries, and opinion polls demonstrate that concerns about environment are a global phenomenon (Brechin and Kempton 1994). Dunlap and York (2008) cite international surveys which indicate that national wealth is not correlated with environmental concerns of a global nature, challenging the claim that the poor are too preoccupied with their material needs to support such "luxury" issues as environmental protection. In the case of Africa, Lotz-Sisitka (2004) acknowledges that mainstream sustainable development discourse espouses

anthropocentric view of environment, in which environment is viewed as "goods and services" within a market-oriented framing of environment as a commodity or resource for human consumption. African societies (and other societies) attribute other values to environment, not only economic value (p. 1).

Anthropological evidence is mixed and shows that indigenous peoples are no more or less ecocentric than people in "developed" nations (Turner 1993; Tsing 1999; Van 
Petegem and Blieck 2006). People hold a variety of values and that some people are pro-wildlife and pro-conservation.

Infield (1988) reflected that though faced with problems of poverty, land shortage and other difficulties directly associated with the existence of the conservation area, respondents strongly supported the protection of wildlife. Allendorf (2007) noted that wildlife is appreciated not only for personal enjoyment, but also because it is the country's wealth. On the other hand, mistrust of local communities as effective stewards of wildlife is also reflected in literature asserting that indigenous peoples view animals and plants as something not worth protecting (Allendorf et al. 2006; Infield 1988), and are capable of overuse and poor decision-making (Netting 1993). Some anthropological evidence points to the fact that "traditional" societies view wildlife from protected areas as pests (Newmark et al. 1993; Infield and Namara 2001; Allendorf et al. 2006; Trusty 2011). However, this dislike can be attributed to global shift from traditional ecocentric values and animistic religions to neo-liberal capitalist "values" imposed by industrial power holders (Milton 2002). The majority of traits that perhaps once enabled traditional societies to live in greater harmony with the environment than more industrialized groups are slowly diminishing (Turner 1993). Many observers have noted that the idea of "progress", "modernity" and "development" is relative and that the enterprise of development actually creates social inequalities and imbalance between humans and environment (Lewis 2005). Western development agencies may be complacent in creating "monocultures of the mind" (Shiva 1993) in which the new "holy grail" of the dominant political elites, the consumerist culture, is perpetuated (Blaser et al. 2004), and culturally specific ways of relating to each other as well as to plants and animals is undermined (Black 2010; Efird 2011; Baines and Zarger 2012).

Considering mixed cross-cultural evidence, it appears that anthrocentrism and ecocentrism are not necessarily culturally determined. The problem is, ethical questions (such as why people of different color or women should have equal standing or why cannibalism is immoral) are not always "academic". Throughout the history of philosophy, religion and ethics, there have been different "rational arguments" for preventing abuse of other beings (human or not). Thomas Aquinas, for example, has postulated that he who kills another's ox does indeed commit a sin, not however, the sin of killing an ox, but rather the sin of inflicting loss of property on another human" (Fudge 2006). Following such moral traditions, social scientists studying human and animal encounters have rarely seen animal death as anything other than the result of cultural practice (such as hunting or whaling - e.g. Kalland 2009), or collateral damage (as in the case of roadkill - e.g. Desmond 2013), or economic interest (as in the case of animal trade - e.g. Thorne 1998), or basic necessity (as in the case of animals used for medical testing or consumption - e.g. Shepard 1993), or symbolic ritual (as in the case of animal sacrifice - e.g. Lévi-Strauss 1968). These acts toward animals rendered animals as culturally, socially or economically significant objects, and not as "victims".

However, these expressions of anthropocentrism are contextually variable and culturally defined. Therefore, in order to return to the question posed in the "Introduction" as to why radical environmentalists are among the least understood, it might be argued that the present-day causes for this lack of understanding of deep ecology perspective lie in anthropocentric bias which is specific to the context of advanced industrial neo-liberal democratic society. The emotional bond between 
humans and animals has been muted by new industrial conditions in which animals and plants are conceived in utilitarian terms (Pluhar 1995; Vining 2003).

\section{Reflection: environmental politics and ethical expertise?}

O'Riordan (1976) reflects that even the weaker forms of anthropocentrism such as conservationism and human welfare ecology are not sustainable since, in the presence of human crisis, they would be sacrificed for the more humanist perspectives. Indeed, despite evidence of heightened global problems such as climate change and biodiversity loss, "environmental considerations continue to be subordinated to economic ones" (Stevenson 2006:280).

While the economic capture approach to preserving biodiversity seems to be part of the mainstream political thinking, the latter approach calls for reflection on political implications for such an approach in the rapidly globalising system of neoliberal democracy. The question of democratic legitimacy and conservation is hotly debated by political observers, social scientists and the media. Some authors point to the empirical evidence demonstrating that government policies do not need to be legitimate in order to be effective or that ecocentric approach may require different forms of democratic representation that would be inclusive of non-human species (Ophuls and Boyan 1992; Oates 1999). One example demonstrating that democratic legitimacy is not necessarily related to success of conservation policies is the creation and maintenance of East African parks by un-democratic colonial governments, as well as evidence of success of environmentally benign dictatorships in the Dominican Republic (Holmes 2010) in pushing forward environmental regulation.

Richard E.F. Leakey, a paleontologist and an activist, became famous for his fight to preserve wildlife in Africa. Leaky espoused the view that the parks were selfcontained ecosystems that had to be fenced in and humans kept out. In order to address the poaching of elephants, Leakey created special, well-armed, anti-poaching units that were authorized to shoot poachers on sight. The poaching was dramatically reduced (http://www.newworldencyclopedia.org/entry/Richard_Leakey) but Leaky was widely criticized by human rights advocates.

Various authors have argued that pursuit of biodiversity conservation will fail without addressing democratic questions of human rights to livelihoods and access to landscapes (Western 1994; Wilshusen et al. 2002, 2003). Robyn Eckersley (2002) has dissed how political dilemmas such as these can be framed within two alternative approaches: ecocentric (deep green perspective approach) and environmental pragmatism (shallow ecology), suggesting that both need to be clearly articulated in order for dialogue between different value holders as well as solutions to biodiversity issues can be found.

Chawla and Cushing (2007) note that an analysis of the world's most serious environmental problems suggests that the effect of private actions is limited unless it is combined with organizing for public change through collective political action (Chawla and Cushing 2007:438). At present, however, there are no empirical cases showing wide popular support for that advocating deep ecology perspective due to the dominance of anthropocentric power holders. Different forms of ecologically enlightened regimes were suggested as an alternative to deliberative democracy, such as panels of "moral experts" (Hardin 1972; Heilbronner 1974; Caldwell 1990; Foreman 1998; Terborgh 1999; Dobson 2003). Without more fully elaborated representation of ecocentric advocates, there are no institutional guarantees that 
other species will be considered in decision-making processes, than their interests will be constantly neglected or at least given low priority (Barry et al. 2002; Eckersley 2004, 2012).

The problem is that no existing political system, democratic or less so, seems to actually employ a panel of "moral experts," particularly the one representing the deep ecological perspective or simply, representing the non-human entities (Lidskog and Elander 2010). While historically the anthropocentric position of individuals "in power" did not threaten bio-diversity due to lower population density and nonindustrial system of production, the present-day anthropocentrism has salient implications for the well-being and even the very survival of non-human species.

While some "green" political parties in Europe (such as the Party for the Animals in The Netherlands) exercise some form of political influence over animal welfare, such influence is proportionally very small and subordinated to other political interests, such as social welfare and economic growth. Not only are individuals or groups within non-human species not distinguished in terms of rights, the very discussion of their basic right to survive is not to be found (for example, domesticated pigs are slaughtered for human consumption and wild boars are subject to possible extinction due to deforestation). Most green political parties are only interested in the welfare of animals that humans consume or keep as pets and not in "wild" animals outside of human instrumental interest (Vining 2003).

To sum up, and returning to the question of limitations of "economic capture" approach, the "moral expert" approach combining ethical elements provided by the deep green perspective might be extremely useful in targeting biodiversity loss. Multi-level environmental governance (Lidskog and Elander 2010) and deliberate democracy (Dobson 2003) do provide room for integration of deep ecology advocates. However, while the inclusion of such moral experts within existing political systems is feasible, there are no guarantees that anthropocentric interests will not dominate, as they do now. The type of "affirmative action" by governments, informed not just by dominant anthropocentric but ecocentric ethics might thus be needed to assure that deep ecology is integrated in political interests.

Taking off the academic hat, the author wants to stress that the underlying ethics supporting gender and racial equality, abolition of slavery, and other human rights have been inconceivable a couple of generations ago. At present, treating human minorities as less worthy will not be socially and politically acceptable in most western liberal circles. If moral considerations underlying present-day social issues such as racism and sexism are to be extended to other species, the (minority) voice of human eco-centric advocates may actually represent the majority voice of all biospheric citizens.

\section{Conclusion}

In this article, we have discussed the differences between anthropocentric and ecocentric perspectives. Anthropocentrism only grants intrinsic value and, in prolongation, rights and interests to human beings. Powerful international organizations such as the United Nations (2012) and the World Bank represent non-human species as ecosystem services or natural resources. Conceiving biodiversity in these utilitarian terms does not guarantee protection of those species that are not directly useful to humanity. It was argued that mass extinction could conceivably come to pass without jeopardizing the survival of the human species. People might be materially 
sustained by a technological biora made to yield services and products required for human life.

In contrast to this anthropocentric paradigm, ecocentrism's proponents assert the intrinsic value of each individual living organism, including humans, plant and animal species and ecosystems. Different dimensions of biospheric altruism include emotional (the feeling of sadness when something valued gets destroyed); cognitive (the judgment that it is wrong to destroy this valued object); and philosophical (intrinsic value of nature) elements.

An analysis of environmental problems suggests that the effect of private actions is limited unless it is combined with organizing for public change through collective political action. It was proposed that the failure of the current political system to address biodiversity loss stems from the fact that ecocentric values are underrepresented in the most powerful strata of society. While private expressions of biophilia are acceptable, the more pronounced publicly expressed deep ecology position is discouraged as radical.

At the onset of this article, we have inquired why "radical environmentalists" are among the least understood of all contemporary opposition movements, not only in tactical terms, but also ethically. Those human advocates that "speak for nature" at international summits and influential political meetings often represent shallow rather than deep ecology position. It was postulated that the present-day causes for this lack of understanding are both structural (in terms of power holders such as political and corporate elites) as well as contextually dependent (current - and thus not "constant" or universal socio-cultural factors that make such anthropocentrism acceptable). The author does see the possibility to reduce this lack of understanding through open articulation of the ethical foundation of deep ecology perspective, combining emotional, cognitive and philosophical underpinnings as an alternative to the current anthropocentric paradigm.

The work of Robyn Eckersley (2002) is particularly instructive in seeing not only why ecocentric activists have trouble "speaking the same language" as "environmental pragmatists" or moderate environmentalists within the shallow ecology movement, but also as an indication of ways forward in regard to potential of continuing to promote such a dialogue. It is not impossible to reconcile deep and shallow ecology visions, as ecocentric and anthropocentric positions are often intimately interlinked (as most mainstream proponents of any form of environmental protection - for human as well as for intrinsic value purposes would probably agree on). Just as pet-owner's commitment to their cat can be an expression of both ecocentric (loving a non-human being) and anthropocentric (the cat is used as a companion, fed cat food possibly originating from other slaughtered animal, etc.) values, so can care for the environment in general be hopefully combined - when both deep ecology and shallow ecology objectives can be clearly stated.

\section{Note}

1. The Lorax is a creation of the children's writer Theodor Seuss Geisel (1904-1991), an American writer and cartoonist better known by his pen name, Dr. Seuss, wrote a children's book about the Lorax, the prototype environmentalist fighting against the capitalist the Once-ler. The Lorax stands up for the "Traffula trees" which are being turned into "thneeds" that "everybody needs". Addressing the Once-ler, the Lorax says:

"I am the Lorax, I speak for the trees.

I speak for the trees, for the trees have no tongues..." 


\section{References}

Allendorf K. 2007. Residents' attitudes toward three protected areas in Southwestern Nepal. Biodivers Conserv. 16: 2087-2102.

Allendorf T, Swe KK, Oo T, Htut Y, Aung M., Allendorf K, Hayek L-A, Leimgruber P, Wemmer C. 2006. Community attitudes toward three protected areas in Upper Myanmar (Burma). Environ Conserv 33: 344-352.

Amérigo M, Aragonés JI., de Frutos B., Sevillano V, Cortés B. 2007. Underlying dimensions of ecocentric and anthropocentric environmental beliefs. Spanish J Psychol. 10(1): 97-103.

Arnold R. 1997. Ecoterror: The violent agenda to save nature. Bellevue (WA): The Free Enterprise Press.

Baines K, Zarger RK. 2012. Circles of value: integrating Maya environmental knowledge into Belizean schools. In: H. Kopnina, editor. Anthropology of environmental education. New York (NY): Nova Science Publishers.

Barry J. Minteer B, Pepperman BT, editors. 2002. Vulnerability and virtue: democracy, dependency and ecological stewardship. In: Democracy and the claims of nature. Lanham (MD): Rowman and Littlefield. p. 133-152.

Begley E. Jr. 2009. Guide to sustainable living. New York: Clarkson Potter Publishers, Inc.

Best S, Nocella II AJ. 2004. "Behind the Mask.". In: Best S, Nocella II AJ, editors. Terrorists or freedom fighters: reflections on the liberation of animals. New York: Lantern Books. p. $9-63$.

Best S, Nocella AJ. 2011. The animal liberation front: a political and philosophical analysis. Herndon, VA: Lantern Books.

Black C. 2010. Schooling the world: the White Man's Last Burden'. Documentary film. Lost People Films [Internet]; [cited 2012 October 31 2012]. Available from: http://www. schoolingtheworld.org.

Blaser M, Feit HA, McRae G, editors. 2004. In the way of development: indigenous peoples, life projects and globalization. London: Zed Books; Ottawa: International Development Research Centre.

Booth C. 2009. A motivational turn for environmental ethics. Ethics Environ 14(1):1-12.

Boyd J. 2007. Non-market benefits of nature: what should be counted in green GDP? Ecol Econ 61(4):716-723.

Brechin SR, Kempton W. 1994. Global environmentalism: a challenge to the post material thesis? Soc Sci Q. 75:245-269.

Brennan A., Lo YS. 2002. Environmental ethics. In: Zalta EN, editor. The Stanford encyclopedia of philosophy. Stanford. p. 1-37.

Brundland Report [Internet] 1987. Our common future; [cited 2012 Oct 31]. Available from: http://conspect.nl/pdf/Our_Common_Future-Brundtland_Report_1987.pdf.

Caldwell LK. 1990. Between two worlds: science, the environmental movement and policy choice. New York (NY): Cambridge University Press.

Catton W, Dunlap R. 1978. Environmental sociology: a new paradigm. Am Sociologist. 13:41-49.

Chawla L, Cushing D. 2007. Education for strategic environmental behaviour. Environ Educ Res. 13(4):437-452.

Churchill W. 2004. Illuminating the philosophy and methods of animal liberation. In: Best S, Nocella II AJ, editors. Terrorists or freedom fighters: reflections on the liberation of animals. Vol. 3. New York (NY): Lantern Books.

Crist E. 2003. Limits-to-growth and the biodiversity crisis. Wild Earth. Spring:62-65.

Crossley M, Watson K. 2003. Comparative and international research in education: globalisation, context and difference. London: Routledge Falmer.

Dawson A. 2007. Greening the campus: contemporary student environmental activism. Radical Teacher [Internet]; [cited 2012 Oct 31] Available from: http://www.amazon.com/ Greening-campus-contemporary-environmental-activism/dp/B000V5KDFQ/re$\mathrm{f}=$ sr_1_sc 2 ? $\mathrm{s}=$ book s\&ie $=\mathrm{UTF} 8 \& \mathrm{qid}=1337737642 \& \mathrm{sr}=1-2$-spell.

De Groot $\bar{R}$. 2002. A typology for the classification, description and valuation of ecosystem functions, goods and services. Ecol Econ. 41(3):393-408.

DesJardins JR. 2005. Invitation to environmental philosophy. New York (NY): Thomson. 
Desmond J. 2013. The requium for a roadkill. In: Kopnina H, Shoreman-Ouimet E, editors. Environmental anthropology: future trends. New York and Oxford: Routledge.

Devall B, Sessions G. 1985. Deep ecology: Living as if life mattered. Salt Lake City (UT): Gibbs Smith.

Dietz T, Fitzgerald A, Shwom R. 2005. Environmental values. Annu Rev Environ Resour. 30:335-372.

Dobson A. 2003. Citizenship and the environment. Oxford: Oxford University Press.

Drengson A, Inoue Y. 1995. The deep ecology movement: an introductory anthology. Berkeley (CA): North Atlantic Books.

Dunlap R, Catton W. 1979. Environmental sociology. Annu Rev Sociol. 5:243-273.

Dunlap R, Catton W. 1983. What environmental sociologists have in common (Whether concerned with 'built' or 'natural' environments). Sociol Inq. 53:113-135.

Dunlap RE, York R. 2008. The globalization of environmental concern and the limits of the postmaterialist values explanation: evidence from four multinational surveys. Sociol Q. 49:529-563.

Eckersley R. 2002. Environmental pragmatism, ecocentrism and deliberative democracy. In: Minteer BA, Taylor BP, editors. Democracy and the claims of nature. Lanham, MD: Rowman \& Littlefield Publishers, Inc. p. 49-69.

Eckersley R. 2004. The green state. Rethinking democracy and sovereignty. London (UK): MIT Press.

Eckersley R. 2012. Global environmental politics. In: Devetak R, Burke A, George J, editors. Introduction to international relations. Cambridge: Cambridge University Press.

Efird R. 2011. Learning the land beneath our feet: an anthropological perspective on placebased education in China. In: Kopnina H, Shoreman-Ouimet E, editors. Environmental anthropology today. New York and Oxford: Routledge.

Ehrenfeld D. 1978. The arrogance of humanism. New York: Oxford University Press.

Ferry L. 1995. The new ecological order. Chicago (IL): University of Chicago Press.

Finsen L, Finsen S. 1994. The animal rights movement in America: from compassion to respect. New York: Twayne Publishers.

Fisher A. 2002. Radical ecopsychology: psychology in the service of life. Albany (NY): SUNY Press.

Foreman D. 1982. Violence and earth first!" Earth First Newsletter 2(4):4.

Foreman D. 1998. Putting the earth first. In: Dryzek JS, Schlosberg D, editors. Debating the earth. The environmental politics reader. Oxford: Oxford University Press. p. 358-364.

Fudge E. 2006. Brutal reasoning: animals, rationality, and humanity in early modern England. Ithaca (NY): Cornell University Press.

Guither HD. 1998. Animal rights: history and scope of a radical social movement. Carbondale (IL): Southern Illinois University Press.

Hardin G. 1972. Exploring new ethics for survival. The voyage of the spaceship Beagle. New York (NY): Viking.

Haring B. 2011. Plastic pandas. Amsterdam, The Netherlands: Nijgh \& Van Ditmar.

Hartig T, Kaiser F, Strumse E. 2007. Psychological restoration in nature as a source of motivation for ecological behaviour. Environ Conserv. 34:291-299.

Heilbronner R. 1974. An inquiry into the human prospect. New York (NY): Harper and Row.

Holmes G. 2010. The rich, the powerful and the endangered: Conservation elites in the Dominican Republic. Antipode. 42(3):624-646.

Hungerford H, Volk T. 1990. Changing learner behavior through environmental education. J Environ Educ. 21(3):8-21.

Infield M. 1988. Attitudes of a rural community towards conservation and a local conservation area in Natal, South Africa. Biol Conserv. 45:21-46.

Infield M, Namara A. 2001. Community attitudes and behaviour towards conservation: an assessment of a community conservation programme around Lake Mburo National Park, Uganda. Oryx. 35:48-60.

Inglehart R. 1977. The silent revolution: changing values and political styles among western publics. Princeton (NJ): Princeton University Press.

Isbell F, Calcagno V, Hector A, Connolly J, Harpole WS, Reich PB, Scherer-Lorenzen M, Schmid B, Tilman D, van Ruijven J, et al.2011. High plant diversity is needed to maintain ecosystem services. Nature. 477:199-202. 
Joye Y, van den Berg A. 2011. Is love for green in our genes? A critical analysis of evolutionary assumptions in restorative environments research. Urban Forestry Urban Greening. 10(4):261-268.

Kahn P. 1997. Developmental psychology and the biophilia hypothesis: children's affiliation with nature. Dev Rev US Climate Change Sci Program. 17(1):1-61.

Kahn PH. Jr, Kellert SR, editors. 2002. Children and nature: psychological, sociocultural, and evolutionary investigations. Cambridge (MA): MIT Press.

Kalland A. 2009. Unveiling the whale: discourses on whales and whaling. Studies in Environmental Anthropology and Ethnobiology Series. New York (NY): Berghahn Books.

Kaplan S. 2000. Human nature and environmentally responsible behavior. J Soc Issues. 56(3):491-508.

Kellert SR, Wilson EO. 1995. Biophilia hypothesis. Frontiers in Ecology and the Environment. Vol. 5. Washington, DC: Island Press.

Kopnina H. 2012a. 'Evaluating education for sustainable development (ESD): using ecocentric and anthropocentric attitudes toward the sustainable development (EAATSD) scale'. Environment, Development and Sustainability. DOI 10.1007/s10668-012-9395-z.

Kopnina H. 2012b. 'Towards Conservational Anthropology: Addressing anthropocentric bias in anthropology'. Dialectical Anthropology, 36(1):127-146.

Kopnina H. 2012c. 'Re-Examining Culture/Conservation Conflict: the view of anthropology of conservation through the lens of environmental ethics'. Journal of Integrative Environmental Sciences, 9(1):9-25.

Korhonen K, Lappalainen A. 2004. Examining the environmental awareness of children and adolescents in the Ranomafana region, Madagascar. Environ Educ Res. 10(2):195-216.

Kortenkamp KV, Moore CF. 2001. Ecocentrism and anthropocentrism: moral reasoning about ecological commons dilemmas. J Environ Psychol. 21:1-12.

Kumar M, Kumar P. 2008. Valuation of the ecosystem services: a psycho-cultural perspective. Ecol Econ. 64(4):808-819.

Lévi-Strauss C. 1968. The savage mind. Chicago: University Of Chicago Press.

Levy SS. 2003. The biophilia hypothesis and anthropocentric environmentalist. Environ Ethics. 25(3):227-246.

Lewis, D. 2005. Anthropology and development: the uneasy relationship. In: Carrier James G editor. A handbook of economic anthropology. Cheltenham (UK): Edward Elgar. p. 472486[Internet] [cited 2012 Oct 31]. Available from: http://eprints.lse.ac.uk/253/.

Liddick DR. 2006. Eco-terrorism: radical environmental and animal liberation movements. Connecticut: Praeger Publishers.

Liddick DR., Evans-Rhodes D, Hall N. 2010. Techniques of neutralization and radical environmentalists: a content analysis of anonymous communiques from the Earth Liberation Front (ELF), Int J Sociol Res. 3(1-2):101-118.

Lidskog R, Elander I. 2010. Addressing climate change democratically. Multi-level governance, transnational networks and governmental structures. Sustainable Dev. 18(1):32-41.

Lotz-Sisitka H. 2004. Positioning Southern African environmental education in a changing context. Howick (South Africa): Share-Net \& Southern African Development Community-Regional Environmental Education Programme.

Louv R. 2005. Last child in the woods: saving our children from nature-deficit disorder. Chapel Hill (NC): Algonquin Books of Chapel Hill.

Lundmarck C. 2007. The new ecological paradigm revisited: anchoring the NEP scale in environmental ethics. Environ Educ Res. 13(3):329-347.

Masters EK. 2004. Animal rights. New York (NY): Gale.

Meadows DH, Meadows DL, Randers J, Behrens III WW. 1972. The limits to growth. New York (NY): Universe Books.

Merchant C. 1992. Radical ecology: The search for a liveable world. New York (NY): Routledge.

Milton K. 2002. Loving nature: Toward an ecology of emotion. New York (NY): Routledge.

Munro L. 2001. Compassionate beasts. Westport (CT): Praeger.

Naess A. 2001. Ecology, community, and lifestyle: outline of an ecosophy. Translated by David Rothenberg. Cambridge: Cambridge University Press.

Netting RM. 1993. Smallholders, householders: farm families and the ecology of intensive, sustainable agriculture. Stanford (CA): Stanford University Press. 
Newmark WD., Leonard NL., Sariko HI, Gamassa D-GM. 1993. Conservation attitudes of local people living adjacent to five protected areas in Tanzania. Biol Conserv. 63:177-183.

Nibert D. 2002. Animal rights, human rights: entanglements of oppression and liberation. New York (NY): Rowman and Littlefield.

Oates JF. 1999. Myth and reality in the rain forest: how conservation strategies are failing in West Africa. Berkley, CA: University of California Press.

Ojala M, Lidskog R. 2011. What lies beneath the surface? A case study of citizens' moral reasoning with regard to biodiversity. Environ Values. 20(2):217-237.

O'Neill J. 2006. Who speaks for nature? In: Haila Y, Dyke C, editors. How nature speaks: the dynamics of the human ecological condition. Durham, NC: Duke University Press Books.

O’Neill J, Spash CL. 2000. Conceptions of value in environmental decision-making. Environ Values. 9(4):521-536.

Ophuls W, Boyan SA. 1992. Ecology and the politics of scarcity revisited. The unravelling of the American dream. San Francisco (CA): Freeman.

O'Riordan T. 1976. Environmentalism. London (UK): Pion Limited.

Quammen D. 1998. The weeds shall inherit the earth. The Independent. p. 30-39.

Pluhar EB. 1995. Beyond prejudice: The moral significance of human and nonhuman animals. Durham (NC): Duke University Press.

Rees W. 1992. Understanding sustainable development. In: Sustainable development and the future of cities. Hamm B, Zimmer G, Kratz S, editors. Proceedings of an international summer seminar; 7-14 September 1991; Bauhaus Dessau. p. 17-40.

Regan T. 1984. The case for animal rights. London (UK): Routledge.

Regan T. 2001. Defending animal rights. Chicago (IL): University of Illinois Press.

Regan T. 2003. Animal rights, human wrongs. Lanham, MD: Rowman \& Littlefield, p. 63-64.

Rosebaugh C. 2004. Burning rage of a dying planet: speaking for the earth liberation front. New York (NY): Lantern Books.

Scarce R. 2004. "Earth First!". In: Krech III S McNeill JR, Merchant C, editors. Encyclopedia of world environmental history. New York (NY): Routledge. p. 356-358.

Scarce R. 2005. EcoWarriors: understanding the radical environmental movement. Walnut Creek, CA: Left Coast Press.

Scarce R. 2011a. If a tree falls: a story of the earth liberation front interview: Rik Scarce, Author of 'Eco-Warriors' [Internet] [cited 2012 Oct 31]. Available from: http:// www.pbs.org/pov/ifatreefalls/eco-warriors-rik-scarce-interview.php.

Scarce R. 2011b. Interview Rik Scarce, author of 'Eco-Warriers' [Internet] [cited 2012 Nov 7]. Available from: http://www.pbs.org/pov/protest-or-terrorism/eco-warriors-rik-scarceinterview.php\#.UJbL8sVrL3A.

Schultz PW. 2001. The structure of environmental concern: concern for self, other people, and the biosphere. J Environ Psychol. 21(4):327-339.

Schwartz SH. 1977. Normative influences on altruism. Adv Exp Soc Psychol. 10:221-279.

"Screaming Wolf" [pseudattributed to Sidney and Tanya Singer]. 1991. A declaration of war: killing people to save animals and the environment. Grass Valley (CA): Patrick Henry Press.

Scruton R. 2012. Think seriously about the planet: the case for an environmental conservatism. Oxford: Oxford University Press.

Seligman C. 1989. Environmental ethics. J Soc Issues. 45:169-184.

Shepard P. 1993. The others: How animals made us human. Washington (DC): Island Press.

Shiva V. 1993. Monocultures of the mind: biodiversity, biotechnology and agriculture. New Delhi (India): Zed Press.

Singer P. 1975. Animal liberation: a new ethics for our treatment of animals. New York (NY): New York review/Random House.

Spash CL. 2009. The new environmental pragmatists, pluralism and sustainability. Environ Values. 18(3):253-256.

Stern PC, Dietz T, Abel T, Guagnano GA, Kalof L. 1999. A value-belief-norm theory of support for social movements: The case of environmentalism. Hum Ecol Rev. 6:81-95.

Stern PC, Dietz T, Guagnano GA. 1998. A brief inventory of values. Educ Psychol Meas. 58:984-1001.

Stern PC, Dietz T, Kalof L. 1993. Value orientations, gender, and environmental concern. Environ Behav. 25:322-348. 
Stevenson R. 2006. Tensions and transitions in policy discourse: recontextualising a decontextualised EE/ESD debate. Environ Educ Res. 12(3-4):277-290.

Sunstein CR, Nussbaum MC. 2004. Animal rights: current debates and new directions. New York (NY): Oxford University Press.

Switzer JV. 2003. Environmental activism. Santa Barbara (CA): ABC-CLIO.

Taylor BR. 1991. The religion and politics of EarthFirst! Ecologist. 21(6):259.

Taylor BR. 1993. Grassroots resistance: the emergence of popular-environmental movements in less-affluent countries. Wild Earth 2(4):43-50.

Taylor BR. 2008. The tributaries of radical environmentalism. J Study Radicalism. 2(1):27-61.

Taylor BR. 2010. Dark green religion: nature spirituality and the planetary future. Berkley, CA: University of California Press

Terborgh J. 1999. Requiem for nature. Washington, DC: Shearwater Books.

The World Bank2012. Biodiversity [Internet] [cited 2012 Oct 31]. Available from: http:// go.worldbank.org/08H25N3QY0.

Thompson GSC, Barton MA. 1994. Ecocentric and anthropocentric attitudes toward the environment. J Environ Psychol. 14:149-157.

Thorne L. 1998. Kangaroos: the non-issue. Soc Anim. 6:167-182.

Trusty T. 2011. From ecosystem services to unfulfilled expectations: factors influencing attitudes toward the Madidi Protected Area. In: Kopnina H, Shoreman-Ouimet E, editors. Environmental anthropology today. New York and Oxford: Routledge. p. 195-295.

Turner T. 1993. 'The role of indigenous peoples in the environmental crisis: the example of the Kayapó of the Brazilian Amazon. Perspect Biol Med. 36(3):526-547.

Tsing AL. 1999. Becoming a tribal elder, and other green development fantasies. In: Li TM, editor. Transforming Indonesian uplands: marginality, power and production. OPA (Netherlands): Harwood Academic Publishers. p. 159-202.

United Nations. 2012. United Nations decade on biodiversity. Strategic goals \& targets for 2020 [Internet] [cited 2012 Oct 31]. Available from: http://www.cbd.int/2011-2020/ goals/.

UN News Center. 2012. With new blueprint in hand, Ban calls for action to chart more sustainable future [Internet] [cited 2012 Oct 31]. Available from: http://www.un.org/apps/ news/story.asp?NewsID $=41077$.

U.S. Department of Justice. 1993. Report to Congress on the Extent and effects of domestic and international terrorism on animal enterprises. Center for the Defense of Free Enterprise [Internet] [cited 2012 Oct 31]. Available from: http://www.cdfe.org/ doj_report.htm

Vanderheiden SJ. 2005. Eco-terrorism or justified resistance? Radical environmentalism and the 'War on Terror'. Polit Soc 33(3):425-447.

Van Petegem P, Blieck A. 2006. The environmental worldview of children: a cross-cultural perspective. Environ Educ Res. 12(5):625-635.

Vining J. 2003. The connection to other animals and caring for nature. Hum Ecol Rev. 10(2): $87-99$.

Watson P. 1993. Earthforce! An earth warrior's guide to strategy. La Canada (CA): Chaco Press Publications.

Weigel R, Weigel J. 1978. Environmental concern. The development of a measure. Environ Behav. 10:3-15.

Wells N, Lekies K. 2006. Nature and the life course. Child Youth Environ [Internet]. [cited 2012 Oct 31] 16(1):1-24. Available from: www.colorado.edu/journals/cye (accessed February 2011)

Western D. 1994. Natural connections: perspectives in community-based conservation. Washington, DC: Island Press.

Wilshusen PR., Brechin SR., Fortwangler L, West PC. 2002. Reinventing a square wheel: critique of a resurgent "protection paradigm" in international biodiversity conservation. Soc Nat Resour. 15:17-40.

Wilshusen PR, Brechin SR, Fortwangler CL, West PC. 2003. Contested nature: conservation and development at the turn of the twenty-first century. In: Brechin SR, Wilshusen PR, Fortwangler CL, West PC, editors. Contested nature: promoting international biodiversity with social justice in the twenty-first century. Albany: State University of New York Press. p. 1-29. 
Wilson EO. 1984. Biophilia: the human bond with other species. Cambridge: Harvard University Press.

Wolfe C. 2003. Animal rites. Chicago (IL): University of Chicago Press.

World Wide Fund WWF. 2012. How many species are we loosing? [Internet] [cited 2012 Oct 31]. Available from: http://wwf.panda.org/about_our_earth/biodiversity/biodiversity/.

Zimmerman ME. 1994. Contesting earth's future: radical ecology and postmodernity. Berkeley (CA): University of California Press.

Zimmerman ME, Callicott JB, Sessions G, Warren KJ, Clark J. 2001. Environmental philosophy: from animal rights to radical ecology. 3rd ed. Upper Saddle River (NJ): Prentice Hall. 